\title{
Symptomatic cholelithiasis as the presentation of pediatric primary sclerosing cholangitis - case series and literature review
}

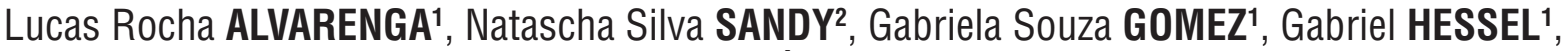 \\ Adriana Maria Alves DE TOMMASO ${ }^{1}$ and Maria Ângela BELLOMO-BRANDÃ ${ }^{1}$
}

\begin{abstract}
Background - Primary sclerosing cholangitis (PSC) is a rare hepatobiliary disorder, whose etiology remains not fully elucidated. Given how rare PSC is in childhood, until the recent publication of a multicenter international collaboration, even data on its characteristics and natural history were scarce. Symptomatic cholelithiasis has not been previously reported as the presentation of PSC. Objective-The aim of this study was the diagnosis of PSC following the initial unusual presentation with symptomatic cholelithiasis, that followed an atypical clinical course that could not be explained by cholelithiasis alone. A literature review was also conducted. Methods - We conducted a retrospective chart review of three patients, who were diagnosed and/or followed at the Clinics Hospital, University of Campinas - Sao Paulo/ Brazil, between 2014 and 2020 . Data analyzed included gender, age of presentation, past medical history, imaging findings, laboratory results, endoscopic evaluation, response to medical therapy and follow-up. Results - Age at time of presentation with cholelithiasis varied from 10 to 12 years. In two of the cases reported, a more subacute onset of symptoms preceded the episode of cholelithiasis. Two patients were managed with cholecystectomy, not followed by any surgical complications, one patient was managed conservatively. Percutaneous liver biopsy was performed in all three cases, showing histological findings compatible with PSC. Associated inflammatory bowel disease (IBD) was not seen in any of the patients. The patients have been followed for a mean time of 3.4 years. Conclusion - PSC and cholelithiasis are both rare in the pediatric population. This study reports on symptomatic cholelithiasis as a presentation of PSC and raises the importance of suspecting an underlying hepatobiliary disorder in children with cholelithiasis without any known predisposing factors and/or that follow an atypical clinical course for cholelithiasis alone.
\end{abstract}

Keywords - Cholelithiasis; sclerosing cholangitis; biliary tract; child.

\section{INTRODUCTION}

Primary sclerosing cholangitis (PSC) is a cholestatic liver disease characterized by chronic inflammation and concentric and obliterative fibrosis, which progressively leads to multifocal bile duct fibrosis, stenosis, cholestasis, disruption of the normal liver parenchyma architecture and, finally, cirrhosis ${ }^{(1)}$. Its etiology remains not fully elucidated, which partially justifies the lack of effective medical therapy for this condition. In adults, PSC is asymptomatic and suspected after the incidental findings of abnormal serum liver tests and/or intrahepatic biliary tree dilation on imaging studies in approximately half of the cases ${ }^{(2)}$. As the disease progresses, several intra- and extra-hepatic complications may develop, such as cholelithiasis and choledocholithiasis, acute bacterial cholangitis, liver abscess, portal hypertension, malignancies (gallbladder, liver and (colorectal) ${ }^{(3)}$. In pediatrics, given the rarity of this disease - with a reported incidence of 0.2 cases per 100,000 children $^{(4)}$ (even more rare children under 2 years of age $)^{(5)}$, there was limited data on the natural history of PSC, until the publication of a recent multicenter international collaboration ${ }^{(6)}$.
Clinical manifestations of PSC in children are variable and similar to those reported in adults ${ }^{(7,8)}$, and when present, they are typically discrete and non-specific, such as hepatomegaly, splenomegaly and jaundice. Other manifestations, historically described include pruritus, right upper quadrant pain, weight loss and fatigue $\mathrm{e}^{(9)}$. The current reality is that pediatric PSC diagnosis is usually established during the investigation and follow-up of abnormal liver enzymes: typically, there is a progressive increase in serum levels of gamma-glutamyl transferase (GGT), alanine aminotransferase (ALT), Immunoglobulin G (IgG), in addition to the presence of autoantibodies, such as antinuclear antibodies (ANA) and smooth muscle antibodies (SMA) ${ }^{(6)}$. When disease is already advanced on the occasion of the diagnosis, manifestations may arise from portal hypertension, such as upper gastrointestinal bleeding from gastroesophageal varices and hypersplenism ${ }^{(10)}$. Recently, a group of researchers validated a pediatric prognosis score for PSC (SCOPE score - sclerosing cholangitis outcomes in pediatrics) that includes biochemical tests (total and fractioned bilirubin, albumin, platelet count and GGT) and imaging (cholangiography) to predict a primary outcome of liver transplantation

Declared conflict of interest of all authors: none

Disclosure of funding: no funding received

Guarantor of the article: Maria Ângela Bellomo-Brandão.

Universidade Estadual de Campinas (UNICAMP), Faculdade de Ciências Médicas, Departamento de Pediatria, Campinas, SP, Brasil. ${ }^{2}$ University of Toronto, Hospital for Sick Children, Department of Pediatrics, Division of Gastroenterology, Hepatology and Nutrition, Toronto, ON, Canada.

Corresponding author: Maria Ângela Bellomo-Brandão. E-mail: angbell@unicamp.br 
and death and a secondary outcome of portal hypertension and hepatobiliary neoplasms, stratifying patients into low, medium and high risk for poor outcomes of liver transplantation or death $^{(11)}$.

Cholelithiasis is among other rare disorders of the gallbladder and biliary tract that can inflict on the pediatric population. As opposed to the adult population, epidemiologic data on the prevalence of cholelithiasis in childhood is relatively scarce. It is well established that hemolysis constitute an important risk factor for pigmented stones and the prevalence is much higher when hemolytic disorders are present ${ }^{(12-14)}$. Beyond hemolysis, other well known risk factors for cholelithiasis are: a positive family history, the presence of underlying ileal disease, use of ceftriaxone, total parenteral nutrition, short bowel syndrome, cystic fibrosis, and, most importantly, obesity was found to be predisposing factors associated with cholelithiasis in children in scholar age and adolescents ${ }^{(13,15)}$. Historically, the estimated prevalence of childhood gallstones was initially reported to range between 0.13 and $0.22 \%{ }^{(16)}$, but later a higher prevalence of $1.9 \%$ in the general pediatric was reported ${ }^{(13)}$. It is arguable that a large part of this perceived increase in prevalence may be due to the advent and diffusion of abdominal ultrasound in recent years, however, increase in pediatric obesity is probably another important driver. Among obese children and teenagers, the reported prevalence of cholelithiasis is as high as $6.1 \%$ in association with metabolic syndrome $^{(17,18)}$

The diagnosis of cholelithiasis happens more often upon the incidental imaging finding in an otherwise asymptomatic patient, or, less frequently - in 6 to $8 \%$ of cases ${ }^{(17)}$ - upon the occurrence of obstructive presentations, such as cholecystitis, cholangitis or pancreatitis. In pediatrics, management for asymptomatic cases remains highly controversial, and in cases when a conservative approach is chosen, there is also no consensus on the frequency of imaging follow-up ${ }^{(17)}$. Symptomatic gallstones typically warrant early cholecystectomy ${ }^{(19)}$. The gold standard elective treatment is laparoscopic cholecystectomy; however, the exploration of the biliary tree remains controversial in the pediatric age group. The options available depend on the expertise of the surgical team and the studies have not yet reached a consensus for a protocol ${ }^{(20)}$.

Although chronic hepatobiliary diseases are reported as a risk factor for the occurrence of gallstones in childhood ${ }^{(21)}$, symptomatic cholelithiasis has not been reported as the presentation of $\mathrm{PSC}^{(4,6,10,22)}$. Thus, the aim of this study was the diagnosis of PSC following the initial unusual presentation with symptomatic cholelithiasis, that followed an atypical clinical course which could not be explained by cholelithiasis alone.

\section{METHODS}

A retrospective chart review of all pediatric patients with primary sclerosing cholangitis, whose initial manifestation was symptomatic cholelithiasis and who were diagnosed and/or followed at the Clinics Hospital, University of Campinas - Sao Paulo/ Brazil, between 2014 and 2020 was conducted. Subjects were identified from a patient registry kept by the senior author. All included patients had persistently abnormal serum liver tests post operatively (following cholecistectomy) and had the diagnosis of PSC confirmed with magnetic resonance cholangiopancreatography (MRCP) or endoscopic retrograde cholangiopancreatography (ERCP), in addition to a liver biopsy.
Clinical and demographic data were collected, including age, gender, presenting symptoms, endoscopic findings, histological features, treatment modalities and clinical course during followup. The present study was approved by the Research Ethics Committee of the State University of Campinas (UNICAMP) under certificate number: 92692718.0.0000.5404. A literature review on pediatric PSC and on cholelithiasis in childhood was also conducted.

\section{RESULTS}

Three patients with the final diagnosis of PSC and initial manifestation of symptomatic cholelithiasis were identified. All cases presented with acute cholecystitis, occasion when the diagnosis of underlying cholelithiasis as the etiology of such presentation was confirmed by abdominal ultrasound (AUS). Two patients were managed with cholecystectomy, not followed by any surgical complications. Following a symptom-free period or during clinical follow-up, there was recurrence of choluria, jaundice, and/or associated elevation of serum liver and canalicular enzymes. The investigation included MRCP in two cases, and ERCP in one. Those studies revealed no evidence of remaining calculi in the biliary tree, while findings compatible with periductal inflammatory reaction in the intrahepatic biliary tract were noted. A liver biopsy was performed, showing histologic findings compatible with PSC in all three cases. All patients underwent upper endoscopy and colonoscopy for the evaluation of possible concomitant inflammatory bowel disease (IBD), not found in any of the patients.

A clinical vignette for each of the cases is provided below, while TABLE 1 summarizes clinical, biochemical, radiological, histological and endoscopic findings, as well as SCOPE score assessment.

\section{Case 1}

A twelve-year-old male, with a previous history of Autism spectrum disorder, presented with jaundice, acholic stools and choluria. Laboratory findings positive for elevation in serum liver and canalicular enzymes, as well as pancreatic enzymes. Careful history taking and review of systems revealed positive complaints of abdominal pain/ discomfort, dark urine and weight loss over the past 4 months. Physical exam was normal; neither hepatomegaly nor splenomegaly was appreciated on physical exam or seen in further imaging studies. Endoscopic ultrasound showed the presence of biliary sludge and choledocholithiasis. He underwent cholecystectomy and liver biopsy. Liver histology chronic demonstrated the presence of chronic liver disease with active biliary inflammation, periductal concentric fibrosis and intense portal bile reaction, nodular transformation of the parenchyma. MRCP status post cholecystectomy revealed distortion of the intra-hepatic biliary tree and segmental dilatation and tapering thinning of the common bile duct (CBD). Ursodeoxycholic acid was initiated to treat PSC with leading to significant biochemical improvement, but not complete normalization of transaminases and bilirubin (dropped roughly by $50 \%$ ), as it is commonly the case in PSC. After the diagnosis of PSC was established, the patient underwent a colonoscopy, to assess for possible presence of concomitant IBD, which was not seen - there was the incidental of a small, $10 \mathrm{~mm}$, sessile polyp, which was removed (histology showed it was an inflammatory polyp). He has been followed for the past 2 years, with no signs of portal hypertension or complaints of underlying IBD. 
TABLE 1. Clinical and laboratory characteristics of primary sclerosing cholangitis (PSC) pediatric patients.

\begin{tabular}{|c|c|c|c|c|c|c|c|c|c|}
\hline $\begin{array}{l}\text { Clinical } \\
\text { features }\end{array}$ & $\begin{array}{l}\text { Initial ultra- } \\
\text { sound }\end{array}$ & $\begin{array}{l}\text { Histologi- } \\
\text { cal report } \\
\text { - cholecys- } \\
\text { tectomy }\end{array}$ & $\begin{array}{l}\text { MRCP, ERCP, } \\
\text { endoscopic } \\
\text { ultrasound }\end{array}$ & Liver biopsy & $\begin{array}{l}\text { Liver and } \\
\text { canalicular } \\
\text { enzymes, } \\
\text { bilirrubins, } \\
\text { and CBC on } \\
\text { presenta- } \\
\text { tion }\end{array}$ & $\begin{array}{l}\text { Liver and } \\
\text { canalicular } \\
\text { enzymes and } \\
\text { CBC at latest } \\
\text { follow-up }\end{array}$ & $\begin{array}{l}\text { Endoscopic } \\
\text { findings }\end{array}$ & $\begin{array}{l}\text { SCOPE } \\
\text { index }^{(11)}\end{array}$ & $\begin{array}{l}\text { Time } \\
\text { of fol- } \\
\text { low-up }\end{array}$ \\
\hline
\end{tabular}

$\begin{array}{lll} & \begin{array}{l}\text { Multiple } \\ \text { calculi seen in } \\ \text { the gallblad- } \\ \text { der and com- }\end{array} & \text { Chronic } \\ \text { Case \#1 } & \begin{array}{l}\text { mon bile duct } \\ \text { (cholelithiasis }\end{array} & \begin{array}{l}\text { moderate } \\ \text { cholecys- }\end{array} \\ \text { Male, } & \text { t choledo- } & \text { titis, with } \\ \text { BMI = } & \text { cholithiasis) } & \text { pseudopi- } \\ \text { Overweight } & \begin{array}{l}\text { Signs of } \\ \text { chronic liver }\end{array} & \text { loric meta- } \\ & \text { plasia } \\ & \text { disease, and } & \\ \text { portal hyper- } & \\ & \text { tension. } & \\ & & \end{array}$

Large (30 $\mathrm{mm})$ hyperechoic round struc-

Case \#2 ture, with

Female, an acoustic

10 years old shadow was

$\mathrm{BMI}=\quad$ visualized on

Normal the common bile duct, consistent with choledocholithiasis.
Endoscopic ultrasound (pre-op): biliary sludge MRCP (post cholecystectomy): distortion of the intra-hepatic biliary tree and segmental dilatation and tapering thinning of the common bile duct.

ERCP: papillotomy performed, but no evidence of calculi was seen. MRCP:

Cholelithiasis and mild chronic cholecystitis. Focal pyloric metaplasia. multifocal irregularities and strictures of the intrahepatic biliary tree, ectasia of the intra and extrahepatic bile ducts with diffuse CBD dilatation (up to $8 \mathrm{~mm}$ ).
Chronic liver disease, with active biliary inflammation, periductal concentric fibrosis and intense portal bile reaction, severe fibrosis, with nodular transformation of the parenchyma.
AST: 279

ALT: 291

AlkPhosp:

1341

GGT: 784

Hgb: 15.2

WBC: 8330

Plt: 251.000

Bilirubin

Total: 4.25

Conjugated: 2.63
AST: 141

ALT: 166:

AlkPhosp: not No signs of measured. GGT: 602

Hgb: 14.6

WBC: 6790

Plt: 318000

Bilirubin

Total: 2.23

Conjugated: 1.3 portal hypertension or IBD seen in the upper endoscopy.

No colonoscopic findings of IBD.

\section{2 years \\ High and 2 risk months}

\begin{tabular}{|c|c|c|c|c|c|}
\hline \multirow{10}{*}{$\begin{array}{l}\text { Chronic and } \\
\text { moderately } \\
\text { active liver } \\
\text { disease, duc- } \\
\text { topenia, and } \\
\text { diffuse nodu- } \\
\text { lar fibrosis. }\end{array}$} & AST: 196 & AST: 38 & \multirow{10}{*}{$\begin{array}{l}\text { Grade } 1 \\
\text { esophageal } \\
\text { varices in } \\
\text { the upper } \\
\text { endoscopy. } \\
\text { No colo- } \\
\text { noscopic } \\
\text { findings of } \\
\text { IBD. }\end{array}$} & \multirow{10}{*}{$\begin{array}{l}7 \\
\text { High } \\
\text { risk }\end{array}$} & \multirow{10}{*}{$\begin{array}{l}5 \text { years } \\
\text { and } 5 \\
\text { months }\end{array}$} \\
\hline & ALT: 140 & ALT: 56 & & & \\
\hline & FALC: 551 & AlkPhosp: 158 & & & \\
\hline & GGT: 439 & GGT: 171 & & & \\
\hline & Hgb: 10.8 & Hgb: 11.0 & & & \\
\hline & WBC: 4420 & WBC: 2410 & & & \\
\hline & Plt: 154000 & Plt: 75000 & & & \\
\hline & Bilirubin & Bilirubin & & & \\
\hline & Total: 2.0 & Total: 0.45 & & & \\
\hline & $\begin{array}{l}\text { Conjugated: } \\
1.71\end{array}$ & $\begin{array}{l}\text { Conjugated: } \\
\text { NA }\end{array}$ & & & \\
\hline
\end{tabular}

\begin{tabular}{|c|c|c|c|c|c|c|c|c|c|}
\hline \multirow{4}{*}{$\begin{array}{l}\text { Case \#3 } \\
\text { Male, } \\
11 \text { years old } \\
\text { BMI = } \\
\text { Overweight }\end{array}$} & \multirow{4}{*}{$\begin{array}{l}\text { Two large } \\
\text { hyperechoic } \\
\text { images (up to } \\
9 \mathrm{~mm} \text { ), with } \\
\text { an acoustic } \\
\text { shadow in the } \\
\text { gallbladder. } \\
\text { (cholelithi- } \\
\text { asis). Signs } \\
\text { of chronic } \\
\text { liver disease, } \\
\text { and portal } \\
\text { hypertension, } \\
\text { significant } \\
\text { splenomegaly }\end{array}$} & \multirow{4}{*}{$\begin{array}{l}\text { Patient did } \\
\text { not undergo } \\
\text { cholecystec- } \\
\text { tomy }\end{array}$} & \multirow{4}{*}{$\begin{array}{l}\text { MRCP: } \\
\text { cholelithiasis, } \\
\text { without associ- } \\
\text { ated dilation of } \\
\text { the biliary; signs } \\
\text { of advanced } \\
\text { chronic liver } \\
\text { disease with } \\
\text { portal hyperten- } \\
\text { sion. }\end{array}$} & \multirow{4}{*}{$\begin{array}{l}\text { Chronic and } \\
\text { moderately } \\
\text { active liver } \\
\text { disease, mod- } \\
\text { erate ductope- } \\
\text { nia, and focal } \\
\text { concentric } \\
\text { periducal } \\
\text { fibrosis. }\end{array}$} & AST: 88 & & \multirow{4}{*}{$\begin{array}{l}\text { No signs of } \\
\text { portal hy- } \\
\text { pertension } \\
\text { or IBD seen } \\
\text { in the upper } \\
\text { endoscopy. } \\
\text { No colo- } \\
\text { noscopic } \\
\text { findings of } \\
\text { IBD. }\end{array}$} & \multirow{4}{*}{$\begin{array}{l}4 \\
\text { Medium } \\
\text { risk }\end{array}$} & \multirow{4}{*}{2 years } \\
\hline & & & & & $\begin{array}{l}\text { ALT: } 83 \\
\text { AlkPhosp: } \\
454 \\
\text { GGT: } 378\end{array}$ & $\begin{array}{l}\text { AST: } 97 \\
\text { ALT: } 109 \\
\text { AlkPhosp: } 301 \\
\text { GGT: } 181\end{array}$ & & & \\
\hline & & & & & $\begin{array}{l}\text { Hgb: } 13.9 \\
\text { WBC: } 4870 \\
\text { Plt: } 160000\end{array}$ & $\begin{array}{l}\text { Hgb: } 13.7 \\
\text { WBC: } 3550 \\
\text { Plt: } 153.000\end{array}$ & & & \\
\hline & & & & & $\begin{array}{l}\text { Bilirubin } \\
\text { Total: } 0.5 \\
\text { Conjugated: } \\
\text { NA }\end{array}$ & $\begin{array}{l}\text { Bilirubin } \\
\text { Total: } 0.44 \\
\text { Conjugated: } \\
\text { NA }\end{array}$ & & & \\
\hline
\end{tabular}

MRCP: magnetic resonance cholangiopancreatography; ERCP: endoscopic retrograde cholangiopancreatography; CBC: complete blood count. SCOPE index ${ }^{(11)}$ : 0-3 (low risk), 4-5 (medium risk), 6-11 (high risk). ALT: alanine aminotransferase (reference range: <35 U/L). AST: aspartate aminotransferase (reference range: 15-60 U/L). AlkPhop: alkaline phosphatase (reference range: 129-417 U/L). GGT: gamma-glutamiltransferase (reference range: 3-22 U/L). Hgb: hemoglobin. WBC: white blood count. Plt: platelets. NA: not available (as conjugated bilirubin not measurable when total bilirubin is low). 


\section{Case 2}

Ten-year-old female, previously healthy, presented with intermittent cramping abdominal pain, jaundice and choluria. An abdominal US confirmed the presence of a cholelithiasis, in keeping with this, laboratory findings revealed elevated serum liver and canalicular enzymes (as can be seen in TABLE 1). She was initially seen by pediatric surgery, and further imaging was completed with MRCP: a distended gallbladder was seen, with at least two calculi identified in the common bile duct (one $20 \mathrm{~mm}$ and the second one $30 \mathrm{~mm}$ ). Endoscopic retrograde cholangiopancreatography with sphincterotomy was performed, but at that time, no clear evidence of calculi passage was seen, just biliary sludge. Repeated MRCP post-procedure showed ectasia of the intra and extrahepatic bile ducts with diffuse CBD dilatation (up to $8 \mathrm{~mm}$ ). Given the persistence of jaundice and choluria, a decision was made to proceed with laparoscopic cholecystectomy. As there was no biochemical improvement, a liver biopsy followed, revealing chronic and moderately active liver disease, ductopenia, and diffuse nodular fibrosis. Small straight esophageal varices (grade 1) were seen during upper endoscopic assessment, while colonoscopy was normal. Ursodeoxycholic acid therapy was started, with satisfactory clinical and laboratory improvement - in this case, normalization of liver enzymes and bilirubin, but not canalicular enzymes, was seen. This patient has been followed for the past 5 years for the diagnosis of PSC, and she remains clinically well, although progressive splenomegaly has been noted. So far, she has not had any episodes of upper GI bleeding and he does not have ascites.

\section{Case 3}

Eleven-year-old male, previously healthy, presented with subacute intermittent abdominal pain associated with nausea and vomiting. A US investigation showed the presence of two hyperechogenic images of around $9 \mathrm{~mm}$ with posterior acoustic shadow, compatible with cholelithiasis. The symptoms persisted and a MRCP confirmed the presence of cholelithiasis, without associated dilation of the biliary; and revealed signs of advanced chronic liver disease with portal hypertension. A liver biopsy was performed and histological findings of chronic and moderately active liver disease, moderate ductopenia, and focal concentric periductal fibrosis were seen. This patient did not undergo a cholecystectomy, his symptoms improved on therapy with Ursodeoxycholic Acid, while his GGT dropped significantly, and his liver enzymes remained elevated around 2-3 times the upper limit of normal. He underwent upper endoscopy and colonoscopy, which were both normal. He has been followed for the past 2 years, with no signs of portal hypertension or complaints of underlying IBD.

None of these patients had another predisposing factor to cholelithiasis other than chronic hepatobiliary disease - PSC diagnosed after the initial event. Viral hepatitis, alpha-1-antitrypsin deficiency, Wilson's disease and autoimmune hepatitis were ruled out in all three patients. These patients have been followed for a mean time of 3.4 years so far, and no other complications were seen - none of the patients had any sign of synthetic liver disfunction/ coagulopathy or decompensated cirrhosis so far.

\section{DISCUSSION}

This study presents an unusual combination of two rare entities in the pediatric population: cholelithiasis and PSC, raising the importance of suspecting and underlying hepatobiliary disorder in children who present with cholelithiasis without any known predisposing factors. In our case series, we report three patients who presented between 10 and 12 years old with symptomatic cholelithiasis and were later diagnosed with PSC, in keeping with a common age of PSC presentation described in the literature ${ }^{(6)}$. The clinical suspicion for PSC in the cases was raised due to carefully clinical history revealing that the presentation was subacute or preceded by chronic nonspecific complaints, and/or because the clinical and laboratory course after a cholecystectomy did not follow the expected course after uncomplicated acute calculous cholecystitis.

The incidence of cholecystectomy in the pediatric population has been steadily increasing over the past 2 decades $^{(23-25)}$, what has been largely related to the rising prevalence of pediatric obesity and overweight ${ }^{(24,26)}$ and the increased ability in making this diagnosis with abdominal ultrasound ${ }^{(18) .}$ It is important, however, to keep into perspective that cholelithiasis can be the presentation of a previously silent underlying hepatobiliary disorder, and that overweight and obesity can coexist with liver and biliary diseases. Despite this raising incidence of cholelithiasis, the controversy in its management persists: there is still a broad variation in the therapeutic strategies adopted among different pediatric centers ${ }^{(21)}$. While in adults, the preferred approach is ERCP with sphincterotomy later followed by laparoscopic cholecystectomy, in pediatrics there is no consensus in management. While in adults, the preferred approach is ERCP with sphincterotomy later followed by laparoscopic cholecystectomy, in pediatrics there is no consensus about management ${ }^{(20)}$. Ursodeoxycholic acid is reported to provide symptomatic relief, however to be relatively ineffective in the actual dissolution of the stone, while laparoscopic cholecystectomy has shown to be a safe and efficient treatment ${ }^{(21)}$, however, to this date, there are no guidelines that clearly dictate the management of cholelithiasis in children and adolescents. It is important to monitor patients post-cholecystectomy in the short and long term: mainly to detect bile duct injury, which may present in the early postoperative period (first 30 days) or later, with cholangitis, biliary peritonitis or peri-anastomosis abscess. In long-term follow-up of these patients, failure in bile drainage can be detected, characterizing stenosis in the anastomosis ${ }^{(26)}$. As illustrated in the present study, PSC should also be considered if there is no clinical or laboratory remission post-cholecystectomy.

Cholelithiasis is listed as part of the differential diagnosis of PSC $^{(27)}$, and some authors consider that the presence of cholelithiasis favors secondary sclerosing over PSC ${ }^{(28)}$. The overlap between these two entities rely on the fact that cholelithiasis may be a complication in up to $8 \%$ of patients with PSC, and it has been suggested that PSC with cholelithiasis may even represent a distinct phenotype of PSC, with poor prognosis in terms of symptoms, relapses and need for transplant ${ }^{(28)}$. It is hypothesized that the susceptibility to cholelithiasis would be secondary to chronic cholestasis ${ }^{(29)}$. Furthermore, in adults, dominant strictures are a well-known complication of PSC that further aggravates cholestasis, increasing the risk of both cholangitis and cholelithiasis, and that can/should be treated with ERCP balloon dilatation or stent placement ${ }^{(8,30)}$. The literature on cholelithiasis in pediatric PSC and cholelithiasis is scarce - the prevalence of this complication in this age group is unknown. In the current case series, we present e cases in which cholelithiasis was the primary presentation that led to the final diagnosis of pediatric PSC - we are not hypothesizing that cholelithiasis was the trigger or the primary insult for liver disease, and we are not suggesting that every child that presents with cholelithiasis warrants and investigation for PSC or underlying liver diseases. However, it 
is important that assure that pediatric patients with cholelithiasis have proper follow-up to ensure biochemical normalization of liver/ canalicular enzymes and bilirubin, as well as resolution of jaundice and/or choluria - or in case, if it is not the case, than an evaluation for an underlying hepatobiliary disease is warranted.

Both PSC and cholelithiasis share some common features in the pediatric population and in the adult world, while some diverging characteristics are reported according to age group. Importantly, this knowledge is also changing recently, as we have been progressively learning more about these biliary disorders in childhood. Small duct PSC was initially thought to be more common in children than adults - earlier and smaller reports found it to affecting 24 to $33 \%$ of children with PSC (vs $<25 \%$ of adult cases) ${ }^{(31)}$, however more recent and multicentric data identified small duct PSC in only $13 \%$ of the pediatric cases ${ }^{(6)}$. Both in children and in adults, small duct phenotype seem to be associated with a milder phenotype and more favorable prognosis ${ }^{(6,11)}$. The antibody most commonly found in children ${ }^{(6,31)}$ and adults ${ }^{(31,32)}$ is pANCA. In children, GGT is a more sensitive marker in diagnosis and response to treatment than Alkaline phosphatase, as the latter is often influenced by bone health related aspects.

The association between PSC and IBD is well-known and strong: the coexistence of these conditions reported in the literature is somewhat similar in children - approximately $75 \% 0^{(6)}$ - and in adults -60 to $80 \%{ }^{(33)}$. In adults, there are strong recommendations for endoscopic assessment/ investigation of IBD in all patients with PSC ${ }^{(34)}$, a practice that has also been sought in the absolute majority of pediatric cases ${ }^{(6)}$, and should be considered standard of care. Interestingly, IBD was not seen in any of our patients, but we recognize that this may be related to relatively short follow-up period. There are still many controversies around the interval in which endoscopic evaluation need to be repeated for IBD surveillance in children who are asymptomatic from a gastrointestinal perspective ${ }^{(31)}$ - one important point being that symptoms do not correlate with colonoscopic findings in children with IBD and PSC. Previous studies reported these association, so-called "PSC-IBD", determined a more severe disease in the pediatric population ${ }^{(35)}$, but recently this paradigm was challenged ${ }^{(36,37)}$, and the largest cohort of pediatric PSC published so far reported PSC-IBD presentation with less advanced stages of liver disease and a slower progression to complications as compared to PSC patients without IBD $^{(6)}$.

Besides IBD, PSC is reported in association with other autoimmune diseases, including autoimmune hepatitis and diseases related to immunoglobulin G4 $(\mathrm{IgG} 4)^{(3)}$. The AIH and PSC overlap is more common in the pediatric population when compared to adults with $\mathrm{PSC}^{(7)}$, and receives the denomination of autoimmune sclerosing cholangitis (ASC) ${ }^{(38)}$. Other well-known associations of pediatric PSC include ABCB4 (MDR3) gene mutation, cystic fibrosis, immunodeficiencies, and Langerhans cell histiocytosis ${ }^{(39)}$. In the present cohort, no features of AIH or other autoimmune or associated conditions were noted.
The SCOPE index, published this year, is the first prognostic tool described for children with PSC: it is reported that it correlates strongly with biopsy-proven liver fibrosis ${ }^{(11)}$. Given the progressive nature of PSC, this index is age-dependent. Applying that score in three cases currently reported, the first two would be classified as high risk ( $9 \%$ annually) for liver transplantation or death, and, as expected, liver histology confirmed the presence of advanced liver fibrosis. Meanwhile, the third patient would be at medium risk for poor outcomes - with an estimated risk of transplantation or death of $3 \%$ annually, according to the referred index.

Chronic Ursodeoxycholic acid therapy is the most commonly described therapy used in the medical management of $\mathrm{PSC}^{(6)}$, and although it is often described that it may lead to a biochemical improvement (as reported in our patients), its role in avoiding disease progression remains questionable - for this reason and given the concern with possible deleterious effects, the society paper from the European Society of Pediatric Gastroenterology, Hepatology and Nutrition advises on the use of doses that do not exceed $15 \mathrm{mg} / \mathrm{kg} /$ day $^{(38)}$. Its use should only be maintained if there is a biochemical response. In our group of patients, the indication and use of this medication followed these premises and was given following a dose regimen of $10 \mathrm{mg} / \mathrm{kg} /$ day.

The retrospective nature and small number of cases are important limitations of many childhood PSC studies, as is the case of our study, but we describe a presentation of PSC not previously described and discussed in the medical literature, raising the importance of having a high index of suspicion for an underlying hepatobiliary disorder in children that present with cholelithiasis without any known predisposing factor, especially if their clinical course does not follow a typical pattern for isolated cholelithiasis.

\section{Authors' contribution}

Alvarenga LR and Gomez GS conceptualized the article, obtained REB approval and collected the data. Alvarenga LR drafted the initial manuscript, reviewed and revised the manuscript, approved the final draft as submitted. Sandy NS contributed to the manuscript, reviewed and revised the manuscript, approved the final draft as submitted. Gomez GS, Dr. Hessel G and Dr. de Tommaso AMA reviewed and revised the manuscript, approved the final draft as submitted. Dr. Bellomo-Brandão MA supervised throughout all the different phases of this study, analyzed the data, reviewed and revised the manuscript, and approved the final draft as submitted.

\section{Orcid}

Lucas Rocha Alvarenga: 0000-0003-1720-9751.

Natascha Silva Sandy: 0000-0002-7744-8984.

Gabriela Souza Gomez: 0000-0002-0466-3640.

Gabriel Hessel: 0000-0002-9884-9381.

Adriana Maria Alves de Tommaso: 0000-0001-7077-9804.

Maria Ângela Bellomo-Brandão: 0000-0002-1145-2606. 
Alvarenga LR, Sandy NS, Gomez GS, Hessel G, de Tommaso AMA, Bellomo-Brandão MA. Colelitíase sintomática como apresentação de colangite esclerosante primária na infância - série de casos e revisão de literatura. Arq Gastroenterol. 2021;58(2):227-33.

RESUMO - Contexto - A colangite esclerosante primária (CEP) é uma doença hepatobiliar rara, cuja etiologia ainda não está totalmente elucidada. Dada a raridade do CEP na infância, até a recente publicação de uma colaboração multicêntrica internacional, mesmo dados sobre suas características e história natural eram escassos. A colelitíase sintomática não foi relatada anteriormente como a apresentação inicial de CEP na infância. Objetivo - O objetivo deste estudo foi o diagnóstico de CEP após a apresentação inicial incomum com colelitíase sintomática, que seguiu um curso clínico atípico que não poderia ser explicado apenas pela colelitíase. Também foi realizada uma revisão da literatura. Métodos - Foi realizada uma revisão retrospectiva dos prontuários de três pacientes, que foram diagnosticados e/ou acompanhados no Hospital das Clínicas da Universidade Estadual de Campinas - São Paulo / Brasil, entre 2014 e 2020. Os dados analisados incluíram sexo, idade de apresentação, história médica pregressa, achados de imagem, resultados laboratoriais, avaliação endoscópica, resposta à terapia médica e acompanhamento. Resultados - A idade no momento da apresentação da colelitíase variou de 10 a 12 anos. Em dois dos casos relatados, um início mais subagudo dos sintomas precedeu o episódio de colelitíase. Dois pacientes foram tratados com colecistectomia, não seguida de qualquer complicação cirúrgica, e um paciente foi tratado de forma conservadora. Biópsia hepática percutânea foi realizada em todos os três casos, mostrando achados histológicos compatíveis com CEP. Doença inflamatória intestinal associada não foi observada em nenhum dos pacientes. Os pacientes foram acompanhados por um tempo médio de 3,4 anos. Conclusão - CEP e colelitíase são raras na população pediátrica. Este estudo relata a colelitíase sintomática como uma apresentação de CEP e levanta a importância da suspeita de doença hepatobiliar subjacente em crianças com colelitíase sem quaisquer fatores predisponentes conhecidos e/ou que seguem um curso clínico atípico.

Palavras-chave - Colelitíase; colangite esclerosante; trato biliar; criança.

\section{REFERENCES}

1. Martins EB, Chapman RW. Sclerosing cholangitis. Curr Opin Gastroenterol. 1999; 15:436-441.

2. Tischendorf JJ, Hecker H, Krüger M, Manns MP, Meier PN. Characterization, outcome, and prognosis in 273 patients with primary sclerosing cholangitis: A single center study. Am J Gastroenterol. 2007;102:107-14.

3. Singh S, Talwalkar JA. Primary sclerosing cholangitis: diagnosis, prognosis, and management. Clin Gastroenterol Hepatol. 2013;11:898-907.

4. Deneau M, Jensen MK, Holmen J, Williams MS, Book LS, Guthery SL. Primary sclerosing cholangitis, autoimmune hepatitis, and overlap in Utah children: epidemiology and natural history. Hepatology. 2013;58:1392-1400.

5. Gidwaney NG, Pawa S, Das KM. Pathogenesis and clinical spectrum of primary sclerosing cholangitis. World J Gastroenterol. 2017;23:2459-69.

6. Deneau MR, El-Matary W, Valentino PL, Abdou R, Alqoaer K, Amin M, et al The natural history of primary sclerosing cholangitis in 781 children: A multicenter, international collaboration. Hepatology. 2017;66:518-27.

7. Couto CA, Terrabuio DRB, Cançado ELR, Porta G, Levy C, Silva AEB, Bittencourt PL, et al. update of the Brazilian society of hepatology recommendations for diagnosis and management of autoimmune diseases of the liver. Arq Gastroenterol. 2019;56:232-41.

8. Bittencourt PL, Cançado EL, Couto CA, Terrabuio DRB, Levy C, Porta G, et al. Brazilian society of hepatology recommendations for the diagnosis and management of autoimmune diseases of the liver. Arq Gastroenterol. 2015;52 Suppl 1:15-46.

9. Broomé U, Olsson R, Lööf L, Bodemar G, Hultcrantz R, Danielsson A, et al. Natural history and prognostic factors in 305 Swedish patients with primary sclerosing cholangitis. Gut. 1996;38:610-15.

10. Fagundes EDT, Ferreira AR, Hosken CC, Queiroz TCN. Primary sclerosing cholangitis in children and adolescents. Arq Gastroenterol. 2017;54:286-191.

11. Deneau MR, Mack C, Perito ER, Ricciuto A, Valentino PL, Amin M, et al. The Sclerosing Cholangitis Outcomes in Pediatrics (SCOPE) index: a prognostic tool for children. Hepatology. 2021;73:1074-87.

12. McEvoy CF, Suchy FJ. Biliary tract disease in children. Pediatr Clin North Am. 1996;43:75-98.

13. Wesdorp I, Bosman D, de Graaff A, Aronson D, van der Blij F, Taminiau J. Clinical presentations and predisposing factors of cholelithiasis and sludge in children. J Pediatr Gastroenterol Nutr. 2000;31:411-17.

14. Gumiero APDS, Bellomo-Brandão MA, Costa-Pinto EALD. Gallstones in children with sickle cell disease followed up at a Brazilian hematology center. Arq Gastroenterol. 2008;45:313-318.

15. Serdaroglu F, Koca YS, Saltik F, Koca T, Dereci S, Akcam M, Akcam FZ. Gallstones in childhood: etiology, clinical features, and prognosis. Eur J Gastroenterol Hepatol. 2016;28:1468-72.

16. Palasciano G, Portincasa P, Vinciguerra V Velardi A, Tardi S, Baldassarre G, Albano O. Gallstone prevalence and gallbladder volume in children and adolescents: an epidemiological ultrasonographic survey and relationship to body mass index. Am J Gastroenterol. 1989;84:1378-82.
17. Tuna Kirsaclioglu C, Çuhacı Çakır B, Bayram G, Akbıyık F, Işık P, Tunç B. Risk factors, complications and outcome of cholelithiasis in children: A retrospective, single-centre review. J Paediatr Child Health. 2016;52:944-9.

18. Frybova B, Drabek J, Lochmannova J, Douda L, Hlava S, Zemkova D et al Cholelithiasis and choledocholithiasis in children; risk factors for development PLoS One. 2018;13:e0196475.

19. Sarrami M, Ridley W, Nightingale S, Wright T, Kumar R. Adolescent gallstones-need for early intervention in symptomatic idiopathic gallstones. Pediatr Surg Int. 2019;35:569-574.

20. Bălănescu RN, Bălănescu L, Drăgan G, Moga A, Caragață R. Biliary Lithiasis with Choledocolithiasis in Children. Chirurgia (Bucur). 2015;110:559-61.

21. Della Corte C, Falchetti D, Nebbia G, Calacoci M, Pastore M, Francavilla R et al. Management of cholelithiasis in Italian children: a national multicenter study. World J Gastroenterol. 2008;14:1383-8.

22. Tibdewal P, Bhatt P, Jain A, Gupta D, Bhatia S, Shukla A. Clinical profile and outcome of primary sclerosing cholangitis: A single-centre experience from western India. Indian J Gastroenterol. 2019;38:295-302.

23. Murphy PB, Vogt KN, Winick-Ng J, McClure JA, Welk B, Jones SA. The increasing incidence of gallbladder disease in children: A 20year perspective. J Pediatr Surg. 2016;51:748-52.

24. Pogorelić Z, Aralica M, Jukić M, Žitko V, Despot R, Jurić I. Gallbladder Disease in Children: A 20-year Single-center Experience. Indian Pediatr. 2019;56: 384-6.

25. Bray F, Balcaen T, Baro E, Gandon A, Ficheur G, Chazard E. Increased incidence of cholecystectomy related to gallbladder disease in France: Analysis of 807,307 cholecystectomy procedures over a period of seven years. J Visc Surg. 2019;156:209-15.

26. Rothstein DH, Harmon CM. Gallbladder disease in children. Semin Pediatr Surg. 2016;25:225-31.

27. Lindor KD, Kowdley KV, Harrison ME. ACG Clinical Guideline: Primary Sclerosing Cholangitis. Am J Gastroenterol. 2015;110:646-59.

28. Almeida R, Arif A, Cheung A. Primary Sclerosing Cholangitis with Cholelithiasis Is a Distinct Phenotype with Worse Symptoms, Decompensation-Free \& Transplant-Free Survival. American Journal of Gastroenterology. 2016;111:S347.

29. Worthington J, Chapman R. Primary sclerosing cholangitis. Orphanet J Rare Dis. 2006;1:41

30. Björnsson E, Lindqvist-Ottosson J, Asztely M, Olsson R. Dominant strictures in patients with primary sclerosing cholangitis. Am J Gastroenterol. 2004;99: 502-8.

31. Adike A, Carey EJ, Lindor KD. Primary sclerosing cholangitis in children versus adults: lessons for the clinic. Expert Rev Gastroenterol Hepatol. 2018;12: 1025-32.

32. European Association for the Study of the Liver. EASL Clinical Practice Guidelines: management of cholestatic liver diseases. J Hepatol. 2009;51:237-67.

33. Hirschfield GM, Karlsen TH, Lindor KD, Adams DH. Primary sclerosing cholangitis. Lancet. 2013;382:1587-99. 
34. Chapman MH, Thorburn D, Hirschfield GM, Webster GGJ, Rushbrook SM, Alexander G, et al. British Society of Gastroenterology and UK-PSC guidelines for the diagnosis and management of primary sclerosing cholangitis. Gut. 2019;68:1356-78.

35. Miloh T, Arnon R, Shneider B, Suchy F, Kerkar N. A retrospective single-center review of primary sclerosing cholangitis in children. Clin Gastroenterol Hepatol. 2009; 7:239-45.

36. Fevery J, Van Steenbergen W, Van Pelt J, Laleman W, Hoffman I, Geboes K, et al. Patients with large-duct primary sclerosing cholangitis and Crohn's disease have a better outcome than those with ulcerative colitis, or without IBD. Aliment Pharmacol Ther. 2016;43:612-20.
37. Ricciuto A, Hansen BE, Ngo B, Aloi M, Walters TD, Church PC, et al. Primary Sclerosing Cholangitis in Children With Inflammatory Bowel Diseases Is Associated With Milder Clinical Activity But More Frequent Subclinical Inflammation and Growth Impairment. Clin Gastroenterol Hepatol. 2020;18:1509-1517-07.

38. Mieli-Vergani G, Vergani D, Baumann U, Czubkowski P, Debray D, Dezsofi A, et al. Diagnosis and Management of Pediatric Autoimmune Liver Disease: ESPGHAN Hepatology Committee Position Statement. J Pediatr Gastroenterol Nutr. 2018;66:345-60.

39. Tabibian JH, Ali AH, Lindor KD. Primary Sclerosing Cholangitis, Part 1: Epidemiology, Etiopathogenesis, Clinical Features, and Treatment. Gastroenterol Hepatol (N Y). 2018;14:293-304. 